\title{
Immatures of Gratiana conformis (Boheman) (Coleoptera, Chrysomelidae, Cassidinae)
}

\author{
Sônia A. Casari $^{1}$ \& Édson Possidônio Teixeira²
}

${ }^{1}$ Museu de Zoologia, Universidade de São Paulo, Caixa Postal 42494, 04218-970 São Paulo-SP, Brazil. casari@usp.br
${ }^{2}$ Instituto Agronômico de Campinas, Caixa Postal 28, 13012-970 Campinas-SP, Brazil. edson@iac.sp.gov.br

\begin{abstract}
Immatures of Gratiana conformis (Boheman) (Coleoptera, Chrysomelidae, Cassidinae). Egg cases and larvae of Gratiana conformis (Boheman, 1854) were collected on Solanum paniculatum L. and reared in laboratory. Egg case, egg, third instar and mature larvae and pupa are described and illustrated. Biological notes and a comparison with the immatures of other Gratiana species and Charidotis gemellata Boheman, 1855, are also presented.
\end{abstract}

KEYWORDS. Brazil; Charidotis; egg case; exuvio-fecal shield; Solanum.

RESUMO. Imaturos de Gratiana conformis (Boheman) (Coleoptera, Chrysomelidae, Cassidinae). Ootecas e larvas de Gratiana conformis (Boheman, 1854) foram coletadas em Solanum paniculatum L. e criadas em laboratório. Ooteca, ovo, larva de terceiro instar, larva madura e pupa são descritas e ilustradas. Dados biológicos e comparação dos imaturos com outras espécies de Gratiana e Charidotis gemellata Boheman, 1855, também são apresentados.

PALAVRAS-CHAVE. Brasil; Charidotis; escudo exuvio-fecal; ooteca; Solanum.

The genus Gratiana includes seven species distributed throughout the American continent, especially South America (Borowiec \& Swietojanska 2009). Five of them are known to feed on Solanum L. (Solanaceae) and tend to be host specific (Siebert 1975; Buzzi 1988; Borowiec 1996, 1999; Olckers et al. 2002 apud Medeiros \& Boligon 2007). Up to now, the larvae described for this genus are those of Gratiana lutescens (Boheman, 1854), G. pallidula (Boheman, 1854) and G. spadicea (Klug, 1829).

Frers (1925) and Mata \& Aravena (1926) described G. spadicea collected on Solanum sisymbriifolium Lam. (Solanaceae); Rolston et al. (1965), G. pallidula collected on Solanum carolinense L. and eggplants and Siebert (1975), G. lutescens reared in laboratory and fed on eggplants, Solanum elaeagnifolium Cav. and S. sodomeum L. var. hermannii Dun. Kvasina \& Ponce de Léon (1985) studied the effects of $G$. spadicea as ectoparasites of Solanum sisymbriifolium and presented a small description and biological notes about larva, pupa and adult of this species. Hill \& Hulley (1995) presented the biology of $G$. spadicea. Medeiros \& Boligon (2007) studied the adaptations of G. conformis (Boheman, 1854) and G. graminea (Klug, 1829) to movement on the hairy leaf surface of their host, on Solanum guaraniticum Hassl.

Gratiana conformis is recorded from the southeast and south of Brazil (from states of São Paulo to Rio Grande do Sul), Argentina, Bolivia and Paraguay. Egg cases and larvae of this species were collected on Solanum paniculatum L. (Solanaceae) ("jurubeba") and reared in laboratory. This is the first time that this host plant is recorded for this species. Herein, the immatures stages are described and illustrated.

\section{MATERIAL AND METHODS}

The egg cases and larvae of G. conformis were collected on Solanum paniculatum (Solanaceae) ("jurubeba") in Bebedouro (Fazenda Figueira, left margin of the Bebedouro stream), state of São Paulo, Brazil, in an agricultural area near a heavy polluted stream, between a soybean field and the ciliary forest. This material was collected on 27.xii.2003 by E. P.Teixeira \& C. Pereira, and reared in laboratory. The branches of the host plant with the egg cases and larvae were kept inside a nylon cage, to obtain the pupae and adults. The material studied was 9 egg cases, 4 larvae of third instar, 4 mature larvae, 2 pupae and 15 adults.

The egg cases, larvae and pupae were fixed in alcohol $70 \%$ and are housed at Museu de Zoologia da Universidade de São Paulo (MZSP). The adults were pinned and are housed at Coleção Entomológica do Instituto Agronômico de Campinas (IACC 7856).

The nomenclature for larval morphology follows especially Lawson (1991) and for plants names, The International Plant Names Index (INPI 2008).

\section{RESULTS}

Egg case (n=9). Length: 3.80-3.93 mm; width: 3.09-3.28 $\mathrm{mm}$. The egg cases are formed by layers of yellowish-brown translucent membrane (Figs. 30-32). One or two eggs are laid between two membranes, starting on first or second membrane, and each egg case has from 3-8 layers of membrane. They are fixed horizontally, underside the surface of leaves.

Egg. Length: 1.37-1.40 mm; width: 0.69-0.77 mm. 
Brownish, elliptical, slightly flattened, and apparently smooth. All the eggs were laid in the egg cases, from 3-8 eggs each egg case.

Third larval instar $(n=4)$ (Figs. 25-29). Length (excluding scoli): 3.30-3.63 mm; width (excluding scoli): $1.62-174 \mathrm{~mm}$. Similar to mature larva, except for size.

Mature larva ( $\mathrm{n}=4)$. Length (excluding scoli): 6.01-7.55 $\mathrm{mm}$; width of thorax (excluding scoli): 2.54-3.71 mm. Body wide and flattened, elliptical, with 16 scoli each side (Figs. 1, 5); each scolus covered with lateral branches; lateral branches and top of scolus with subapical region articulated (Fig. 21). After fixation, body cream with head partially yellowish; claws and urogomphi brownish; pronotum with two brownish patches (Figs. 1, 33, 34). General integument with stout berry-like setae (Fig. 17); dorsally with two transverse rows on each tergite (one row each fold) (Fig. 23); ventrally, more concentrated on abdomen, disposed in transversal dense band on each abdominal ventrite. Spiracles at the end of elevated tubules (Fig. 20).

Head (Figs. 9, 15, 16) hypognathous rounded, mostly hidden under pronotum. Epicranial suture very weak, Y-shaped, defined especially by different coloration: frons whitish and remainder area outside of frontal arms, yellowish; median endocarina well developed, extending between frontal arms. Stemmata very prominent (Fig. 18), six on each side (Figs. 2, 9): a row of three near frontal arms, one latero-externally, and two frontally, below antenna. Frons (Fig. 9) bearing 12 moderately long setae on each side. Each epicranial plate bearing 7 setae. Fronto-clypeal suture complete (Fig. 16), at middle very difficult to see. It looks-like, under stereomicroscope, a fold and under optical microscope and SEM, incomplete at middle (Fig. 16). Clypeus (Figs. 7, 16) band-like, subtrapezoidal, notched and microsetose laterally at base; each side with one short seta and one campaniform sensillum. Labrum (Figs. 7, 16) transverse, slightly narrowed distad; distal margin distinctly emarginate at middle; fore angles rounded; two short setae near anterior margin and two long on each side in basal third; four campaniform sensilla medially at base, disposed in trapezoidal way. Epipharynx (Fig. 8) membranous, partially covered with fine spines; each side of anterior margin with three stout setae, tooth-like; emargination of anterior margin with six short, stout and straight setae; two plates and three sensorial pores on each side medially. Antennae (Fig. 19) with two antennomeres; basal antennomere short, annular; distal elongate with sensory appendix and three short setae at apex; one seta laterally near middle. Mandibles (Figs. $10,11)$ symmetrical, palmate, 6-toothed; two ventral teeth sharpened, others with rounded apices; two dorsal setae near base; three campaniform sensilla near base: two below setae and one above them. Maxilla and labium (Fig. 6) almost totally membranous; only labial and maxillary palpi, mala and prementum slightly sclerotized. Maxilla: cardo indistinct; stipes elongate bearing two long setae and one campaniform sensillum; mala with rounded apex, bearing four stout setae ventrally and two dorsally; palpiger bearing two long setae and three campaniform sensilla; maxillary palpi with two palpomeres; basal palpomere wider than long, bearing two setae and one campaniform sensillum ventrally and one seta dorsally; distal palpomere elongate bearing one campaniform sensillum externally, one seta internally and several small peg-like sensilla at apex. Labium: prementum partially fused to postmentum, bearing ventrally, two very short setae on each side and two campaniform sensilla medially, near anterior margin, one long seta near base of each palpus and one short seta on each side, basally; postmentum bearing four long setae disposed in semicircular row near anterior margin. Labial palpi with one palpomere, bearing several small peglike sensilla at apex and one campaniform sensillum on side. Hypopharynx membranous with five pairs of campaniform sensilla near base; distal half microspiny.

Pronotum expanded laterally and anteriorly; two pairs of scoli (Figs. 1, 5) at anterior margin and one scolus each side. Pronotum covering head, narrower and longer than meso- or metanotum. Mesothorax bearing three pairs of scoli; median pair shorter than others; metathorax bearing two pairs of scoli; anterior pair shorter. Meso- and metanotum, each with one transverse fold. Mesonotum bearing, latero-anteriorly, one annular spiracle on each side (Fig. 20). Legs moderately long, inserted separately ventro-laterally; 4-segmented, setose, setae inserted on small tubercles (Figs. 4, 22); coxa wide and short, with setae more concentrated latero-medially; trochanter fused to femur, shorter than wide, with numerous setae and 5 campaniform sensilla near base; tibia narrower than femur, longer than wider, with several setae (Figs. 4, 15, 22); claws (Figs. 3, 4, 15, 22) sclerotized and wide, very curved, bearing one setae at base; apex of claw surpassing tibial latero-ventral margin.

Abdominal segments I-VII slightly narrowed to apex, each with one dorsal fold; laterally with one annular spiracle, what is smaller than thoracic spiracle; segment VIII band-like dorsally; segments I-VIII bearing laterally one scolus on each side; segments VII-VIII longer; segment IX with a pair of long sclerotized upward urogomphi arising from the dorsum and extending anteriorly on abdomen (Figs. 1, 33-35); anal tube extrusible, microspinose (Fig. 24) and with setae articulated near apex (Fig. 35) and more concentrated lateromedially. The anal tube enables the larva to add excrement to the urogomphi (Rolston et al. 1965) (Fig. 34).

Exuvio-fecal shield. Present, formed by exuviae and excrements fixed on urogomphi, partially concealing the larva.

Pupa (n=2) (Figs. 12-14). Length: 7.43-8.72 mm; width of prothorax: 4.25-4.49 mm. Elliptical, flat and wide. After fixation color cream. Head not visible from above. Pronotum transverse, lateral and anterior margins rounded; setous near middle; setae withish; posterior margin notched laterointernally making hind angles prominent; anterior and lateral margins with setiform projections (Fig. 12) of varied sizes, articulated subapically; 5th and 6th projections on each side of anterior margin and some latero-posterior longer; hind angles bearing three projections; several projections near middle. Meso- and metanotum glabrous. Abdominal segments I-V with one wide, flat lateral scolus (more flattened and wider than those of larva) decreasing in size posteriorly; segments 

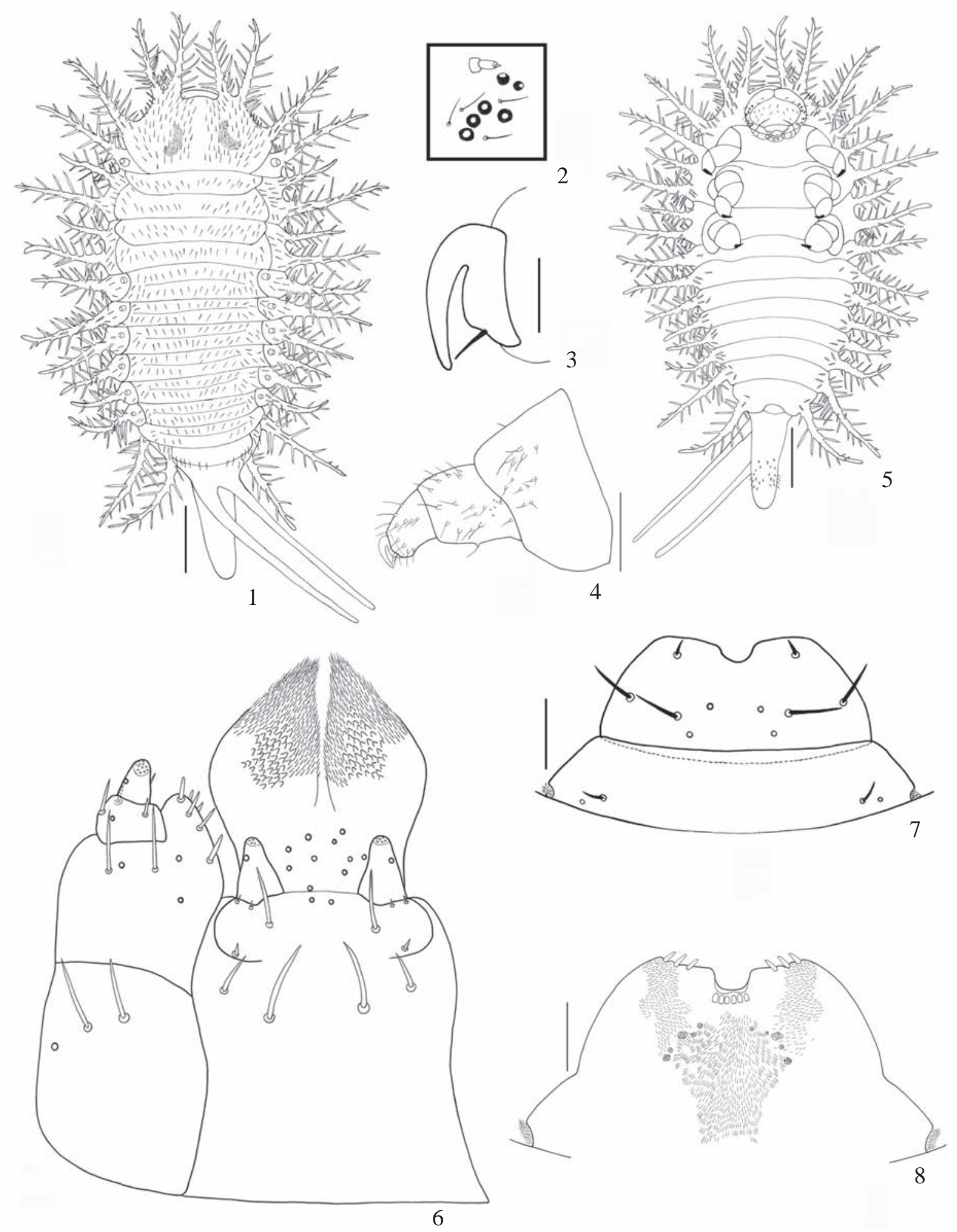

Figs. 1-8. Gratiana conformis (Boheman). Mature larva: 1, 5, dorsal, ventral; 2, stemmata diagram; 3, claw; 4, leg; 6, maxilla and labium; 7, clypeus and labrum; 8, epipharynx. Bars $=1 \mathrm{~mm}$, except figs. $1,5=10 \mathrm{~mm}$ and fig. $4=5 \mathrm{~mm}$.

I-VII with one spiracular opening and one short seta on each side, diameter of spiracle decrease posterad; each side of segments VI-VIII with narrow, short and smooth projections directed ventrally; segment IX with a pair of upwards and long urogomphi, slightly longer than the three distal tergites; segment $\mathrm{X}$ tubular and ventral. The pupa is attached to the host plant by means of last abdominal segment.

Exuvio-fecal shield. Present. 


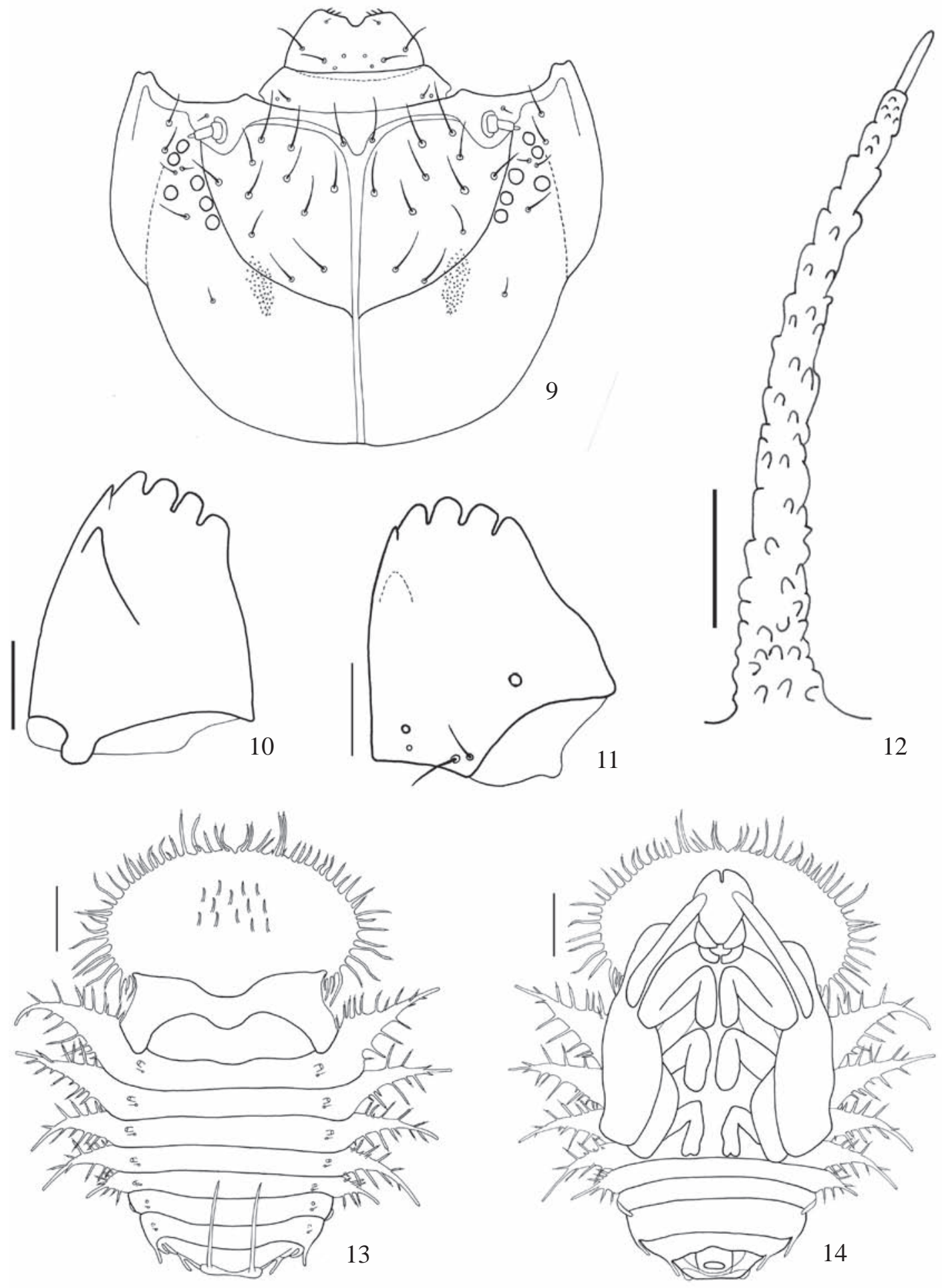

Figs. 9-14. Gratiana conformis (Boheman). Mature larva: 9, head capsule (dorsal opened); 10, 11, mandible (ventral, dorsal). Pupa: 12, pronotal setiform projection; 13, dorsal; 14, ventral. Bars $=10 \mathrm{~mm}$, except fig. $11=1 \mathrm{~mm}$.

\section{DISCUSSION}

In field conditions, the larvae of G. conformis were found feeding upper surface of the leaves. During the field collections one Tingidae species was found on the same host plant. In the laboratory the pupation occurred on both, upper and under surfaces of the leaves. The larvae and pupae bear the old skin on the dorsum, fixed at the urogomphi. The prepupal period lasted one day and the pupal from 6-7 days. Fifteen emerged adults were kept in laboratory laid eggs and after 39 days the larvae of first instar emerged.

"On the economically positive side of phytophagy, some 

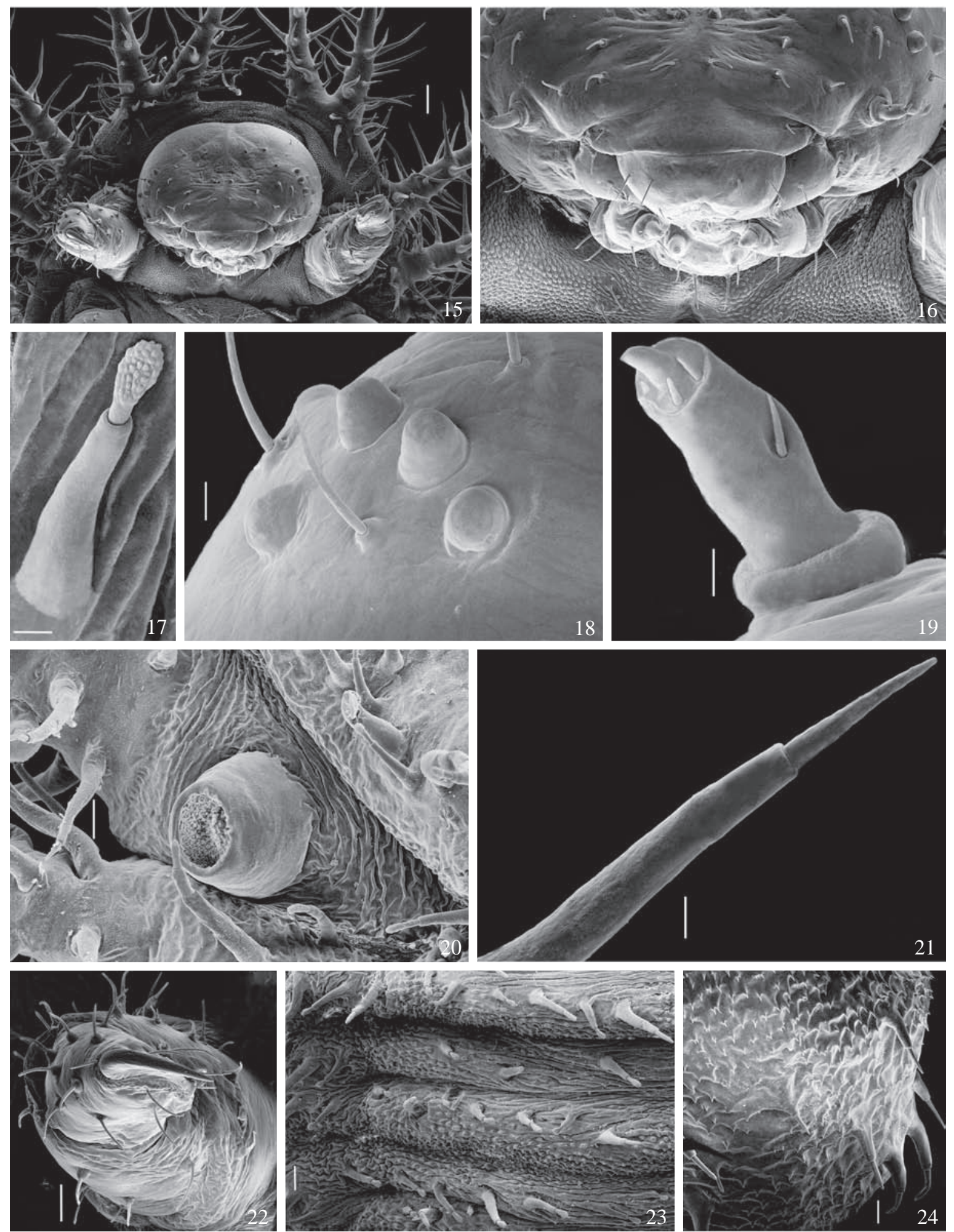

Figs. 15-24. Gratiana conformis (Boheman). Mature larva: 15, head and prothoracic legs (frontal); 16, apex of head (dorsal); 17, seta; 18, stemmata; 19, antenna; 20, thoracic spiracle; 21, scolus; 22, leg (frontal); 23, detail of dorsum of abdomen; 24, detail of anal tube. Bars: fig. $15=200 \mu \mathrm{m}, 16,22=60 \mu \mathrm{m}$, $18,20,24=20 \mu \mathrm{m}, 19,21=10 \mu \mathrm{m}, 23=40 \mu \mathrm{m}$ and $17=10 \mu \mathrm{m}$.

cassidines are very useful as biological control agents for several weedy plants” (Chaboo 2007: 41). Gratiana species are included in the group of open leaf-feeders (Becker \& Friero-Costa 1987, 1988 apud Chaboo 2007), and have been used in South Africa to control Solanum sisybriifolium
(Solanaceae), an invasive weed from South America (Siebert 1975; Hill \& Hulley 1995, 1996; Julien \& Griffiths 1998 apud Chaboo 2007).

The host plants recorded for known larvae of Gratiana species are: G. conformis, feed on Solanum paniculatum (new 

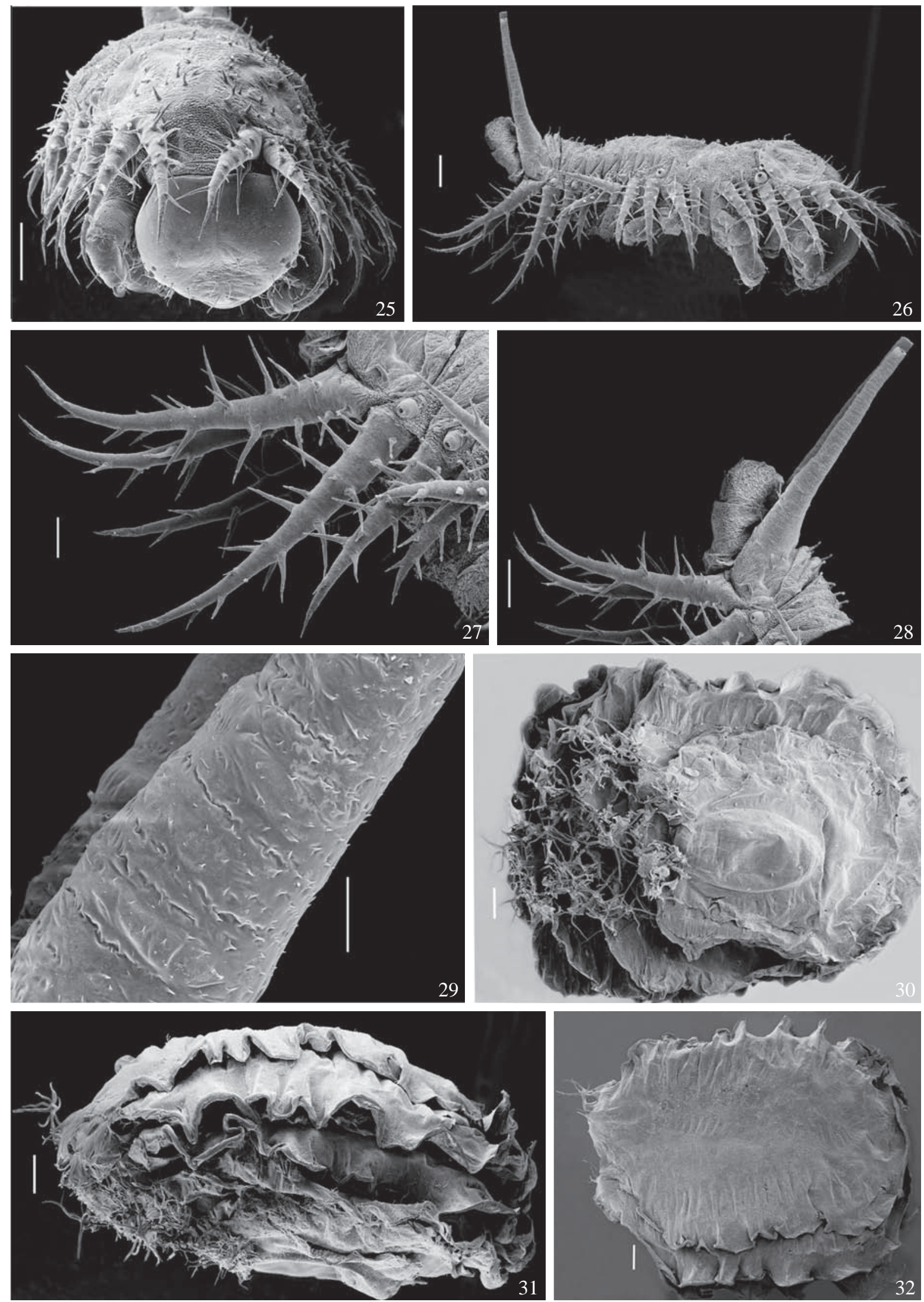

Figs. 25-32. Gratiana conformis (Boheman). Third instar larva: 25, frontal; 26, lateral; 27, scoli; 28, side of last abdominal segments (segments VI-IX and anal tube); 29, detail of urogomphi. Egg case: 30-32, ventral, lateral and dorsal. Bars $=200 \mu \mathrm{m}$ except fig. $29=20 \mu \mathrm{m}$ and $28=100 \mu \mathrm{m}$. 

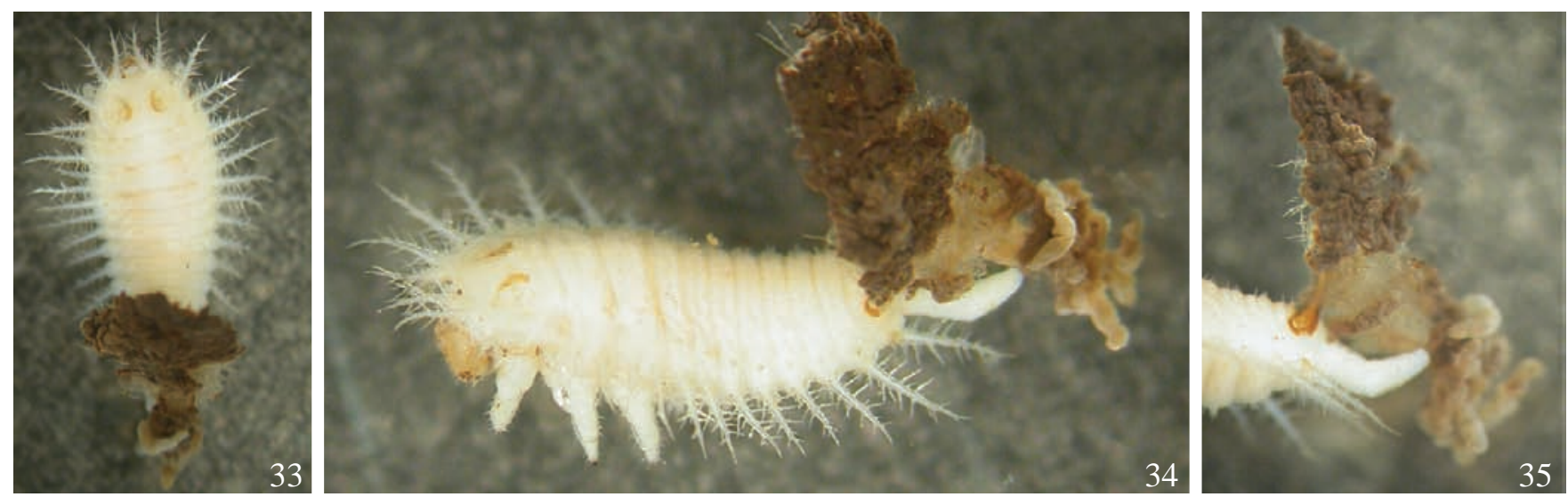

Figs. 33-35. Gratiana conformis (Boheman). Mature larva: 33, dorsal; 34, laterodorsal; 35, apex of abdomen.

record) and S. guaraniticum (Medeiros \& Boligon 2007); G. graminea on Solanum guaraniticum (Medeiros \& Boligon 2007); G. lutescens and G. pallidula, on eggplant, Solanum elaeagnifolium and S. sodomeum var. hermannii (Siebert 1975); G. pallidula, on Solanum carolinense, the source of infestation for eggplant (Rolston et al. 1965), S. xanti Gray and S. elaeagnifolium (Coquillet 1892 and Riley 1882 apud Rolston et al. 1965); G. spadicea feeding on Solanum sisymbriifolium (Frers 1925; Mata \& Aravena 1926).

The eggs of G. conformis, G. lutescens and G. spadicea are laid in masses, forming egg cases. In G. pallidula, the majority of the eggs are laid singly and only about $30 \%$ are in masses. The egg cases are formed by some overlapped translucent membranes, each varying in number of membranes (from three to eight).

The position of the egg case on the leaves is variable. In G. conformis, in the field, the egg cases were fixed on under surface of leaves, being two nearest to base of leaf blade (near petiole), on the mid rib and one in middle of the leaf, while in laboratory, in contrast to the field observations, some egg cases were on upper surface of leaves. It was found until three egg cases on the same leaf. In G. lutescens the egg cases were laid under surface of leaves, usually in slight hollow or against a vein (Siebert 1975). In G. pallidula, the egg cases were fixed on the upper surface of the foliage, especially on the leaves near terminal, stacked vertically in one or two tiers (Rolston et al. 1965). In G. spadicea, in both sides of leaves, near or far nervures (Hill \& Hulley 1995; Mata \& Aravena 1926) or laid on the under surface of leaves (Frers 1925).

The egg shapes are similar in all species, but the coloration is variable. Eggs of $G$. conformis are brownish; those of $G$. lutescens are yellow green, turning more yellow towards the end of incubation period (Siebert 1975); those of G. pallidula are cream to light brownish (Rolston et al. 1965); of G. spadicea are white, slightly pinkish or creamish, with transversal striae in large magnification (Mata \& Aravena 1926) or greenish (Frers 1925).

Larvae of $G$. conformis are brownish and the typical pattern of the "leaf damage" made by the first instar is similar to a lace, resulting in a skeletonized leaf. The first instar of G. lutescens prefer young leaves; later instars feed also on older leaves and petioles and even green stems, and may skeletonize leaves or devour entire leaves and young growth (Siebert 1975). Larvae of G. pallidula are yellow-green and both, larvae and adults cut small circular holes in the foliage and the larvae occasionally scars developing fruits (Rolston et al. 1965). Larvae of $G$. spadicea are whitish, slightly yellow passing to light green when start to eat; first instar cut small circular areas of epidermis of leaves, not perforating the leaves (Mata \& Aravena 1926). According to Hill \& Hulley (1995) early instars of $G$. spadicea seemed to feed more on the surface of leaves, leaving small holes; later instars are voracious feeders and at high densities may skeletonize leaves.

As observed by Medeiros \& Boligon (2007) the kind of movement of the larvae on the leaf surface is related especially to the tarsungulus [claw] shape: in G. conformis heavily sclerotized, hook-like and with a sharp tip in continuation with distal edge of the tibia. The hook aperture increases from basal to distal end. According to them, the larva "move mainly by anchoring the tarsungulus hook on the trichome rays, but occasionally they also move by inserting the tarsungulus tip directly into the epidermis", and this kind of movement is only possible due to tarsunguli shape.

In $G$. conformis, the pupae are attached to the plant by means on last abdominal segment. In the laboratory, they are attached to the upper and under surfaces of leaves; $G$. pallidula are usually attached to upper surface of leaves (Rolston et al. 1965); in G. spadicea, the majority is attached on the stems and petioles (Hill \& Hulley 1995). It is cream in $G$. conformis; pale green in $G$ lutescens, blending well with foliage (Siebert 1975); green in G. spadicea (Frers 1925; Kvasina \& Ponce de Léon 1985; Mata \& Aravena 1926).

Comparing the immatures of Gratiana conformis with the description of G. lutescens, G. pallidula and G. spadicea, it was observed that the general shapes of the egg cases, larvae and pupae are very similar. Comparing the larval structures, the antenna presents two antennomeres in G. conformis and $G$. lutescens and three in $G$ spadicea (not described in G. pallidula); the distal antennomere presents at apex, one conical large and three setiform short sensilla in G. conformis and three small appendices in G. spadicea (not described in 
the others). Mandibles 6-toothed in G. conformis, 5-toothed with a ventral small protuberance (Frers 1925) or 6-toothed (Mata \& Aravena 1926) in G. spadicea (not described in the others). Maxillary palpi with two palpomeres in G. conformis and three palpomeres in G. spadicea (not described in the others). Comparing the pupae, the anterior margin of pronotum of $G$. conformis and G. pallidula presents $5^{\text {th }}$ and $6^{\text {th }}$ setiform projections on each side, starting in middle, longer than others while in G. lutescens and G. spadicea the $3^{\text {rd }}$ and $4^{\text {th }}$ on each side are longer. The pronotum of $G$. conformis and $G$. lutescens is setous near middle, considered by Siebert (1975) as slender straight spines.

The larva and pupa of $G$. conformis are similar to Charidotis gemellata Boheman, described by Fernandes \& Buzzi (2007). Comparing both species it was observed that the host plants are different: Solanum paniculatum (Solanaceae) to G. conformis and Pithecoctenium crucigerum (L.) Gentry (Bignoniaceae) to C. gemellata; one or two eggs are laid between two layers of membrane forming an egg case with three to eight layers in G. conformis and the eggs are laid individually on the substrate with a membrane dorsally, not covering totally the egg in C. gemellata. Besides, it was observed the following differences between the larvae ( $C$. gemellata parenthesized): clypeus with one short seta and one campaniform sensillum on each side (glabrous); labrum with three setae and two campaniform sensilla on each side (18 setae); mandibles 6-toothed (4-toothed). The pronotum of pupa is marginated by 26-30 spiniform projections on each side (11 projections each side).

Acknowledgements. To Cláudio Pereira for helping the collection of the material, Carlos Campaner (Museu de Zoologia da Universidade de São Paulo) for identification and the anonymous reviewers for comments.

\section{REFERENCES}

Borowiec, L. 1996. Faunistic records of Neotropical Cassidinae (Coleoptera, Chrysomelidae). Polish Journal of Entomology 65: 119-251.

Borowiec, L. 1999. A world catalogue of the Cassidinae (Coleoptera: Chrysomelidae). Wrocaw, Biologica Silesiae, $x i+476$ p.
Borowiec, L. \& J. Swietojanka. 2009. Cassidinae of the World - an interactive manual (Coleoptera, Chrysomelidae). <http://www. biol.uni.wroc.pl/cassidae/katalog\%20internetowy/index.htm>. Access 20/05/2009.

Buzzi, Z. 1988. Biology of Neotropical Cassidinae. p. 559-580. In P. Jolivet, R. Petitpierre \& T. H. Hsiao (eds.). Biology of Chrysomelidae. Dordrecht, Kluwer Academic Publishers, xxiv+615 p.

Chaboo, C. S. 2007. Biology and phylogeny of the Cassidinae Gyllenhal sensu lato (tortoise and leaf-mining beetles) (Coleoptera: Chrysomelidae). Bulletin of the American Museum of Natural History 305: 1-250

Fernandes, F. R. \& Z. J. Buzzi. 2007. Descrição dos imaturos e primeiro registro de planta hospedeira de Charidotis gemellata Boheman (Coleoptera, Chrysomelidae, Cassidinae). Revista Brasileira de Entomologia 51: 234-238.

Frers, A. G. 1925. Metamorfosis de coleópteros argentinos. Physis 8: 8292.

Hill, M. P. \& P. E. Hulley. 1995. Biology and host range of Gratiana spadicea (Klug, 1829) (Coleoptera: Chrysomelidae: Cassidinae), a potential biological control agent for the weed Solanum sisymbriifolium Lamarck (Solanaceae) in South Africa. Biological Control 5: 345-352.

Hill, M. P. \& P. E. Hulley. 1996. Suitability of Metriona elatior (Klug) (Coleoptera: Chrysomelidae: Cassidinae) as a biological control agent for Solanum sisymbriifolium Lam. (Solanaceae). African Entomology 4: $177-123$.

INPI - The International Plant Names Index. 2008. <htttp://www.ipni.org/>. Access 19/05/2009.

Kvasina, M. L. \& R. Ponce de Léon. 1985. Nuevos aportes a la biologia de Gratiana spadicea (Klug, 1829) (Coleoptera, Chrysomelidae) y su relacion com la planta huesped Solanum sisymbriifolium Lamarck, 1797 (Solanaceae). Boletin de la Sociedad Zoologica del Uruguay 3: 9-15.

Lawson, F. A. 1991. Chrysomelidae (Chrysomeloidea) (=Cassidinae, Cryptocephalidae, Megalopodidae, Sagridae, etc.), p. 568-585. In: F. W. Stehr, (eds.) Immature Insects, v. 2. Dubuque, Kendall / Hunt Publishing Co., xvi $+974 \mathrm{p}$.

Mata, A. B. \& R. O. Aravena. 1926. Metamófosis de um coleóptero del género Gratiana. Revista de la Sociedad Entomologica Argentina 1: 31-34.

Medeiros, L. \& D. S. Boligon. 2007. Adaptations of two specialist herbivores to movement on the hairy leaf surface of their host, Solanum guaraniticum Hassl (Solanaceae). Revista Brasileira de Entomologia 51: 210-216.

Rolston, L. H., R. Mayes \& R. Edwards 1965. Biology of the eggplant tortoise beetle (Coleoptera, Chrysomelidae). Journal of the Kansas Entomological Society 38: 362-366.

Siebert, M. W. 1975. Candidates for the biological control of Solanum elaegnifolium Cav. (Solanaceae) in South Africa: laboratory studies on the biology of Gratiana lutescens (Boh.) and Gratiana pallidula (Boh.) (Coleoptera, Cassididae). Journal of the Entomological Society of South Africa 38: 297-304. 